\title{
WHAT RESEARCH SHOWS ABOUT MATHEMATICS TEACHERS' LEARNING NEEDS: EXPERIENCE FROM LATVIA
}

\author{
Ilze France \\ Dace Namsone \\ Liga Cakane \\ University of Latvia, Latvia
}

\begin{abstract}
The implementation of new skills (competencies) according to education regulation documents in 2006 - 2008 demanded a change in the Mathematics and Science teaching practice in Latvia. Work on the new education reform started this year (2015). The aim of the research is to look for the answers to the following questions - do the changes in learning approach occur and are teachers' skills sufficient for organizing a different teaching process? What are the learning needs expressed by teachers and concluded by experts? The range of cognitive activity, collaboration and focusing on students' learning are the criteria set for lesson observations. The research shows a tendency that changes envisioned in education policy resolutions fail to be reflected in school practice. In many cases, the demonstrated teachers' instructional skills were insufficient. The research shows the clear need to improve the instructional skills - to develop higher order cognitive skills (HOCS) oriented learning activities, to organize students' collaboration etc. The research proves the existence of the need to improve teachers' reflection skills and points to the deep contradiction between teachers' performance in the classroom and their own understanding about it.
\end{abstract}

Keywords: lesson observation, mathematics teachers' needs.

\section{Introduction}

The basic education guidelines in effect for the mathematics learning process in Latvia are described as self-expressive and creative, analytically critical, evaluative, social (collaborative), communicative, mathematical, learning and practical activity oriented and have marked the course towards mastering competences in different subjects (Table 1). The new regulations for education planning in Latvia envision implementation of the competencies approach into the general education content. However, before the implementation of the change commences, it is crucial to understand the status quo of the currently effective education guidelines in the classroom and to identify the teachers' learning needs. Math teachers' learning needs is the focus of this article. 
Table 1. Regulations governing the guidelines of mathematics teaching content

- Ministry of Education of the Republic of Latvia, Department of Learning Content, Standard for Primary Education Mathematics, Riga 1992, SIA Lielvārds, p.64

- Ministry of Education and Science of the RL, Center for Education Content and Examination, State Standard for Primary Education, Riga 1998, Lielvārds, p.32

- Cabinet of Ministers, Regulations No.1027, Riga, December 19, 2006, Regulations on State Standard in Primary Education http://likumi.lv/doc.php?id= $150407 \&$ from $=$ off

- Cabinet of Ministers, Regulations No 715, Riga, September 2, 2008 Regulations on State General Secondary Education Standard and General Secondary Education Subjects' Standards http://likumi.lv/doc.php?id=181216

- National Development Plan of Latvia 2014-2020, December 2012, adopted by the Saeima of the RL. http://www.pkc.gov.lv/images/NAP2020\%20dokumenti/ 20121220_NAP2020_apstiprinats_Saeima.pdf

\section{Theoretical background}

\section{What is the essence of the current guidelines of the education regulations?}

Many countries have started new Organization for Economic Co-operation and Development (OECD) Program for International Student Assessment (OEDC PISA) outcomes related reforms that call for the need to improve students'progress. Government resolutions 2006 undertaken in Latvia to mark a course towards promoting students'competencies continue in the new state education policy resolutions 2014 .

The aspects of competencies in math contents - were incorporated as aspirations to perform scientific inquiry (France, 2010), to create a link with real life and to implement the application of information technologies, as is being done in a number of other countries.

Scientific inquiry as a teaching and learning approach is an action model. Metaphorically speaking it is like a multi layered piece of cake. Implementation of scientific inquiry means cognitive immersion, organization of an interested opinion exchange, acceptance of various answers and improvement of collaboration and competencies, which by their deeper essence differs from the traditional teachers' approach - transmitting information. To have the ideas occur in classroom practice means to focus on the cognitive immersion, collaboration and learning mode.

\section{What understanding should the teachers possess?}

It is important to emphasize that the constructivist opinion about learning allows the teacher to implement the priorities specified in education regulations on a professional level in the classroom (Cobern \& Loving, 2008, Niaz, 2011 etc.).

It is important for teachers to understand that constructivism cannot be applied as an algorithm in the classroom leading to a panacea (Tobiass \& Duffy, 
2009; cited from Niaz, 2011). Efficient teaching and learning of scientific inquiry in the school is impossible without teachers' understanding of the concept, diversity and continuity of the scientific inquiry, as well as the following skills: ability to identify the learning outcomes of scientific inquiry and their conformity to the expected results; effective use of the teaching and learning strategies for scientific inquiry and effective communication of feedback on students' scientific inquiry.

On the lesson level it means to set learning outcomes, to refresh students' experiences, to hook and to interest them, to offer cognitive and metacognitive strategies that are helpful for the knowledge construction, to provide feedback, etc. Therefore, progress follow up is an integral part of the priorities specified in the learning content regulations.

Hattie's research (2012) showed that learning to learn including clarity, challenging learning outcomes, the feedback to improve the performance, etc. gave an effect size of $0.75,0.56$; and 0.72 respectively.

The changes specified in the policy resolutions can be incorporated in teachers' practices only if each teacher implements paradigm shift from transmitting information to a constructivism based approach.

\section{What is the context for teachers' activities?}

If we view implementation of the reforms in the context of the historic experience, the last decade of the twentieth century can be described as a nonstop period of change in the education system in Latvia. When the political power shifted at the beginning of the 1990ies and the first generation education standards were implemented, the teachers were granted freedom of choice to independently design the learning process. However, the paradox is that even today in continuing education classes teachers keep asking: "Tell me, what is the correct way of teaching this!" Just a decade ago about $40 \%$ of chemistry teachers were willing to return to the historically dominating strictly set procedures which used directives to clearly specify what had to be taught and in what way. (Namsone, 2010). While the shift in learning paradigms is occurring around the world, Latvia still largely witnesses the traditional teaching that stems out of the historic tradition for teachers to follow specific directives and manifests in usage of a single text book from 'cover to cover', 'teaching for exams', etc.

According to Van Driel et al. (2001) practical theories that guide teachers in teaching are based on practical knowledge. Teachers' practical knowledge is constructed by the teachers in the context of their work integrating experimental knowledge and formal knowledge. Math and science teachers' formal knowledge can be described as follows "chemists know the chemistry content, however they lack the knowledge of how to merge the content with high level pedagogic outcomes" (Ege et.al., 1997). This is obvious examining the scope of mathematics teachers' study program content for mastering the subject content, knowledge about students, teaching and learning, instruction and assessment 
techniques, classroom management, etc.; in other words, the launching pad to become a teacher.

Implementation of changes in the classroom demands from teachers' not only new knowledge and skills but also a change in their beliefs about what teaching is. It means to act in dynamic situations. A teacher needs a critical mind and ability to reflect. Reflection can be in action and on action (Niemi \& JakkySihvonen, 2009). For example, in the teacher education in Finland teachers' competence must include the readiness to analyse the situation like a researcher and to make conclusions and decisions to act or to change something in a given situation (Niemi \& Jakky-Sihvonen, 2009). Consequently, when new teacher learning models are developed in Latvia it has to be taken into account that teachers' education has never met such demands and most teachers lack appropriate learning experience.

Unfortunately, the context is not change friendly. The teachers' professional standard is not working properly in Latvia. Traditionally, regulations specifying the demands set for teachers are unclear, blurred and filled with obscure phrases. Teachers' performance is measured by the traditional method of summed up evaluations of students' performance (centralized examinations, academic Olympics etc.) which contradicts the changes in the education policy regulations.

\section{What has already been researched?}

During lesson observation in schools between 2009 and 2011, a group of experts working in the National Center for Education (NCE) under the development project 'Science and Mathematics', witnessed a range of successful teaching performances. Nevertheless, experts concluded that in frequent cases there was a discrepancy between the actual performance of the teachers in the classroom and their understanding of what they were doing, which was demonstrated during discussions after lessons. For example, investigating the skills of Latvian chemistry teachers from 2009 to 2011 the contradiction between the actual situation in the classroom and background analysis confirms the idea that in order to develop effective scientific inquiry organization skills, teachers must have analysis and reflection skills (Volkinsteine et al., 2014). Math teachers' beliefs and change of it was described by Šapkova (2013).

\section{Research methodology}

The following criteria were set to observe students learning range of cognitive activity, collaboration and learning mode (outcomes, feedback). It corresponds to the aspects in education policy documents $(1998,2006)-$ analytical and critical thinking; social (collaborative) skills and learning and its practical application. The criteria focused to teachers' skills: appropriate teaching methods, methods' techniques and the mode of professional collaboration. 


\section{Research questions}

1. What do lesson observations reveal about the students' learning in mathematics lessons according to criteria selected?

2. Do teachers demonstrate the necessary skills to organize students' learning?

3. What are mathematics teachers' learning needs?

\section{Data collection and analysis}

The following research methods were used for data collection and analyses: lesson observation and analyses, teachers' questionnaires, analyses of experts' conclusion, analyses of documents.

A total of 57 math lessons (grades 5-12; 10 schools representing all school types; 97\% math teachers from employed in these schools) were observed in 2013 and analyzed. The observations were carried out by specially trained experts from the Centre for Science and Mathematics Education University of Latvia, each with 10-15 years of experience.

The experts used a specially developed e-observation sheet for transcript and analysis. Each lesson was transcribed by each expert who observed the lesson according to the specified criteria using a Likert scale $(0$ - not present; 1 - minor presence; 2 - moderate presence; 3 - present) and confirmed the evaluation with comments. The expert also transcribed the conversation with the teacher after the lesson. Experts' comments were coded. Content analysis was used.

A teachers' needs questionnaire adapted from PROFILES project served as a tool to determine teachers' understanding of the skills they needed to improve. 27 respondents - math teachers ( $77 \%$ from employed in these schools) took part in 2013. The questionnaire consisted of 36 questions on teachers' confidence of certain skills and emphasis on professional development. Respondents evaluated each of their skills according to the Likert scale $(0$ - don't know, cannot; 1 - can do satisfactorily; 2 - can do well; 3 - can do very well) and their own learning needs ( 0 - definitely no need to master; 1 - rather not need; 2 - necessary to master; 3 - very necessary to master). The questionnaire included questions about the skill to facilitate higher order cognitive skills HOCS and improve students' learning through collaboration; to define and communicate learning outcomes; to use different formative assessment strategies and provide meaningful feedback for the students; to choose goal appropriate methods. Six questions covered the teachers' reflection skills - recording the facts and using them as basis for analyses; focusing on the efficiency of the lesson; providing feedback to colleagues and accepting it; awareness of teachers' own strength and weaknesses; immersion in their own professional activity in order to improve teaching.

The numerical data were processed using R 3.1.2. software. 


\section{Results}

The results were analyzed according to criteria. The criteria set to observe students learning: range of cognitive activity, collaboration and learning mode (outcomes, feedback).

The lesson observations reveal that only $29 \%$ of the lessons indicated the use of HOCS on an acceptable level (2-3 in scale). The following example (Table 2) demonstrates a low level of cognitive activity in a math lesson for Grade 7 led by teacher P. Students learned how to identify is the particular number a right solution of the linear inequality. The teacher starts the lesson with demonstration how to solve the problem. Then she dictates the algorithm and gives the students 15 similar problems to 'drill'.

Table 2. Passage of lesson transcription from 6 minute to 27 minute

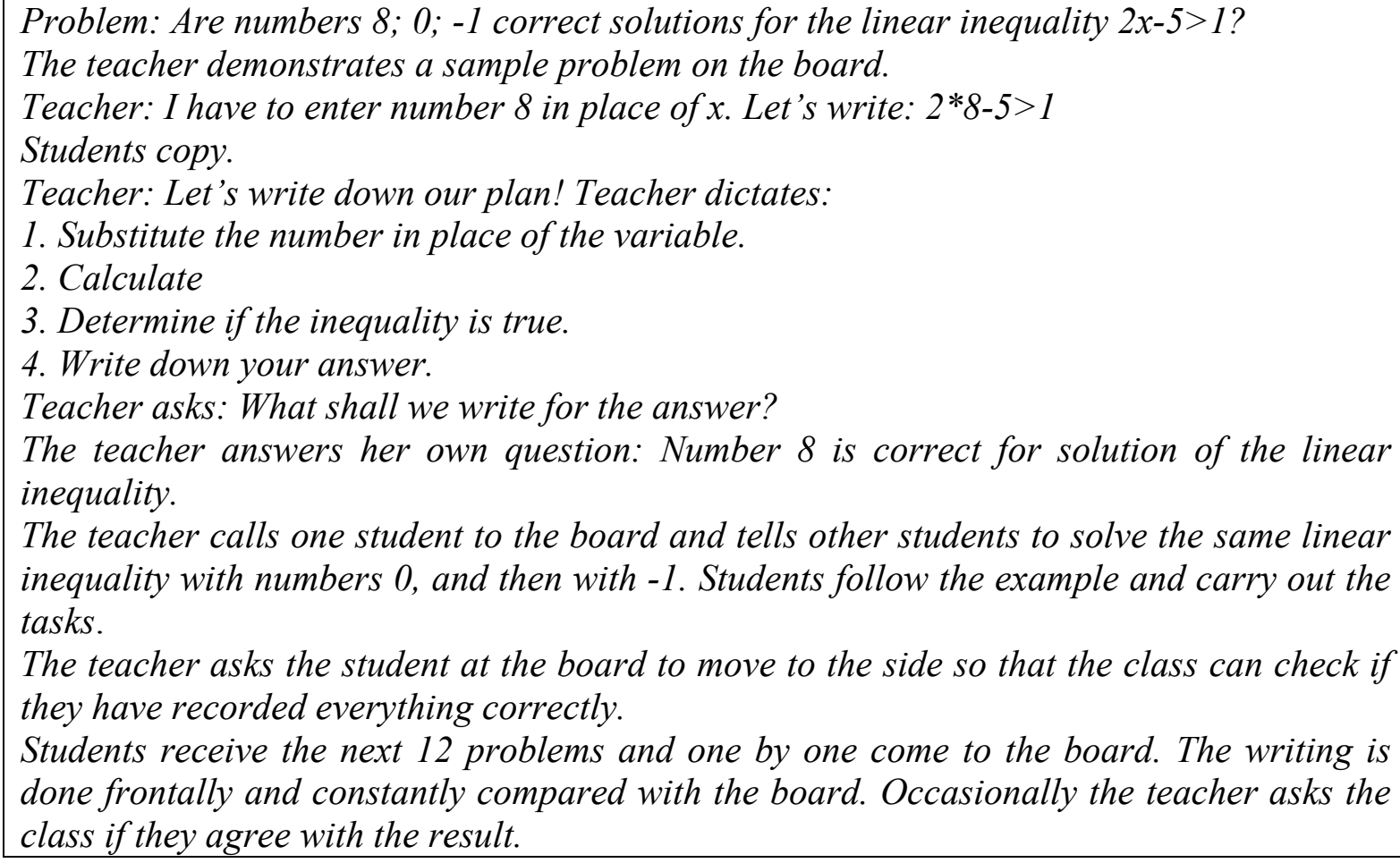

2. Calculate

3. Determine if the inequality is true.

4. Write down your answer.

Teacher asks: What shall we write for the answer?

The teacher answers her own question: Number 8 is correct for solution of the linear inequality.

The teacher calls one student to the board and tells other students to solve the same linear inequality with numbers 0 , and then with -1 . Students follow the example and carry out the tasks.

The teacher asks the student at the board to move to the side so that the class can check if they have recorded everything correctly.

Students receive the next 12 problems and one by one come to the board. The writing is done frontally and constantly compared with the board. Occasionally the teacher asks the class if they agree with the result.

Successful student collaboration was observed in $54 \%$ of the lessons. In $52 \%$ of the lessons teachers failed to communicate the learning outcomes or make sure that students had understood what they were supposed to learn. The usage of elements of feedback techniques was observed in $60 \%$ of lessons. However, the experts' reveal that while the teacher did receive information about students' learning, he/she failed to communicate feedback that would help the students improve their performance.

Table 3 shows the data about teachers' skills to organize studies according to the criteria. 
Teachers evaluated their skills, including the skills needed for students' learning in the lesson (Table 4) - the ones experts evaluated during lesson observation.

Table 3. Teachers' skills demonstrated to organize learning (\% of the observed lessons)

\begin{tabular}{|l|c|c|c|c|}
\hline Criteria & present & $\begin{array}{c}\text { moderate } \\
\text { presence }\end{array}$ & $\begin{array}{c}\text { minor } \\
\text { presence }\end{array}$ & not present \\
\hline $\begin{array}{l}\text { Appropriateness of methods } \\
\text { used to achieve the outcome }\end{array}$ & 23 & 44 & 30 & 4 \\
\hline Technique of the methods & 19 & 35 & 42 & 4 \\
\hline $\begin{array}{l}\text { Collaboration organization } \\
\text { skills }\end{array}$ & 20 & 20 & 32 & 29 \\
\hline
\end{tabular}

Table 4. Teachers' self-evaluation (\% of teachers)

\begin{tabular}{|l|r|r|l|l|}
\hline & $\begin{array}{l}\text { Can do very } \\
\text { well }\end{array}$ & Can do well & $\begin{array}{l}\text { Can do } \\
\text { satisfactorily }\end{array}$ & $\begin{array}{l}\text { Do not } \\
\text { know, do not } \\
\text { know how }\end{array}$ \\
\hline $\begin{array}{l}\text { Facilitate students' higher } \\
\text { level thinking skills }\end{array}$ & 9 & 13 & 61 & 17 \\
\hline $\begin{array}{l}\text { Can communicate the } \\
\text { planned learning outcomes } \\
\text { to students }\end{array}$ & 27 & 57 & 16 & 0 \\
\hline $\begin{array}{l}\text { Provide valid feedback to } \\
\text { students }\end{array}$ & 8 & 57 & 35 & 0 \\
\hline
\end{tabular}

The questionnaire reveals that the teachers admit the need to improve their teaching skills (for example, $78 \%$ of teachers evaluate as poor or non-existent their skills to facilitate students' thinking). As the teaching approach is related with evaluation of one's own performance and change in teachers' opinion, it was also important to find out if teachers saw the need to develop their analyzing and reflection skills. At the same time, the questionnaire shows that about $30 \%$ of respondents fail to understand the need to improve the following skills - evaluate personal strong and weak sides, analyze personal performance in order to be able to improve, provide useful feedback to colleagues or receive it. $53 \%$ of teachers support the need to analyze their performance and to improve it. However, only $23 \%$ admit the skill to evaluate their own performance, etc. as needed or very needed.

\section{Discussion and conclusions}

Analyses of the data acquired during lesson observation reveals that quite frequently teaching in the classroom is performed as transmitting information with including separate elements of new learning aspects. Learning organization in the observed math lessons can be largely described as a lack of clear learning 
outcomes and feedback for students, dominating low level cognitive activity and frontal work with the whole class of students. This leads to a conclusion that the change of teaching and learning paradigms has just begun.

Teachers demonstrated the usage of appropriate methods and collaboration models in only approximately half of the lessons. The data obtained during observation of the learning process show that teachers' performance in the classroom demonstrates insufficient skills of managing teaching techniques and organization of collaboration. This point to the obvious need to incorporate practical training in teachers' professional learning program.

More thorough analyses revealed that the number of teachers who chose the most efficient method to reach the outcomes (67\%) outnumbered those who did not. This allows one to conclude that they succeed in traditional teaching emphasized largely working on lower order cognitive skills (LOCS). This corresponds to research which shows teachers may well be more comfortable with a traditional teaching mode (Olson, 2003) characterized historically for the East (Pavlova, Pitt, 2003).

This evidenced the existence of a gap between the priorities described in the education policy resolutions from 2006 and the reality in the classroom in 2013.

Lesson analyses and experts' conversations with teachers after the lesson conclude that in frequent cases there was a discrepancy between the actual performance of the teachers in the classroom and their understanding of what they were doing. This matches the findings of previous research (Volkinšteine et al., 2014) and points to insufficient teachers' analyses and reflection skills. Here (Table 5) we have included a sample of math lesson Grade 12 transcript on rotating spheres and the conversation with the teacher $\mathrm{R}$.

Table 5. Comparison of the information from observation and conversation

\begin{tabular}{|c|c|}
\hline From lesson transcript & $\begin{array}{c}\text { From experts conversation with the teacher } \\
\text { after the lesson: }\end{array}$ \\
\hline $\begin{array}{l}\text { The new content is being explained. The } \\
\text { teacher is speaking and asking questions } \\
\text { to the students. Three students are } \\
\text { answering. The teacher begins the } \\
\text { sentence and expects one student to } \\
\text { answer; then she goes on saying the next } \\
\text { word of the answer herself until the } \\
\text { definition is completed. The students write } \\
\text { down the definition; they copy it from the } \\
\text { board. }\end{array}$ & $\begin{array}{l}\text { At the beginning of the conversation I found } \\
\text { out what the expected learning outcome in } \\
\text { this lesson was. The teacher was telling me } \\
\text { that she had planned that the students would } \\
\text { create their own rotary spheres definitions. } \\
\text { The teacher was pleased because the students } \\
\text { had accomplished the task. However when } \\
\text { asked what allows her to conclude that the } \\
\text { students had really managed to create their } \\
\text { own definitions, the teacher failed to answer } \\
\text { the question. }\end{array}$ \\
\hline
\end{tabular}


The discrepancy manifested itself even stronger in the comparison of lesson observation data and teachers' self-evaluation. While HOCS development in the classroom showed some kind of correspondence to the observation $(29 \%$ to $22 \%$ ), communication of learning outcomes revealed significant difference $84 \%$ of teachers think that their skills of communicating the reachable outcome are good or acceptable. However, experts in only $49 \%$ of lessons observed such outcome.

Data interpretation showed that teachers typically fail to see the need to develop their analyses and reflection skills - the need to acquire these skills was ranked the lowest (compared to the skills listed). At the same time the aforementioned skills have the highest 'do not know' percentage, which might mean that teachers lack an opinion regarding the necessity of these skills and that teachers do not see them as part of their professional competencies. A discrepancy between teachers' self-defined learning needs and experts' observations does exist.

Responses to the questionnaire repeatedly demonstrate the need for improving teachers' reflection skills and also points to the deep controversy between teachers' performance in the classroom and their understanding of what they are doing, which was mentioned before. This complicates organization of teachers' learning because 'a person has to learn what he/she is not aware he/she lacks'.

In order to achieve real changes in the classroom, math teachers have to immerse themselves in their own and their colleagues' practices by analyzing and reflecting on them. The primary need for teachers' education is to create learning situations that offer a different kind of experience, discussion, opinion exchange, practicing analyses, reflection on one's own and colleagues' learning; that is, immersion, at the same time learning the techniques of the particular methods. It is impossible to improve all the skills at the same time. Therefore, immersion in one's own practice should be the priority which would allow then gradually to develop the spectrum of other skills. No changes will occur if the teacher keeps 'failing to know that he/she does not know'.

It is obvious that teachers cannot acquire these skills through teachers', something new". A completely different form and essence is needed and this corresponds with the conclusions of other research (Fulan, 2011, Barber \& Mourshed, 2007). In the historical context things are complicated by the fact that experts (educators, authors) learn at the same time with teachers because they too need a change of paradigms in their opinions and have to acquire a different experience of learning so that afterwards they would be able to organize teachers' learning in a different environment.

Teachers' learning needs can be addressed through implementation of long term teachers' learning models that allow them to acquire learning as the concept modelling and learning through collaboration experience. For this purpose, the following elements of classroom practice based learning models 
can be used - collaboration groups, action research (Kemis \& Taggart, 2000), collaboration networks (Rauch et al., 2014) as well as learning in practice jointly observing and analyzing lessons (Namsone, Cakane, 2014), which is going to be the subject of further research.

This might seem too general, not focused on math education, but in practice it does! Implementation of a new philosophy means changing people's beliefs about a different understanding of learning on the whole and about an efficient lesson. Only then can one focus on how to include the particular math teaching methods in the lesson. Stopping at particular teaching methods will leave one on a superficial level which will never change teachers' beliefs and practices.

\section{References}

Barber, M. \& Mourshed, M. (2007). How the world's best performing school systems come out on top. McKinsey \& Co. On http://www.smhc-cpre.org/wp-content/uploads/ 2008/07/how-the-worlds-best-performing-school-systems-come-out-on-top-sept072.pdf

Cobern, W., Loving, C. (2008). An essay for educators: Epistemological realism really is common sense. Science \& Education, 17, 425-447.

Ege, S., Coppola, B., Lawton, R. (1997). The University of Michigan Undergraduate Chemistry Curriculum 1. Philosophy, Curriculum and the Nature of Change. Journal of Chemical Education, 75 (12).

France, I. (2010). The Research Skills in Mathematics Content for Grades 7 to 12, their Implementation into Practice. Society, Integration, Education. (pp. 207 - 214). Rezekne: Rezekne Higher Educ Inst.

Fullan, M. (2011). Whole system reform for innovative teaching and learning. In ITL Research. Innovative teaching and learning research: 2011 Findings and Implications (pp.30-39). Retrieved from http://www.itlresearch.com/research-a-reports/2011-itlresearch-findings

Hattie, J. (2012). Visible learning for teachers. Maximizing impact of learning. London and New York: Routledge.

Kemmis, S., \& McTaggart, R. (2000). Participatory action research. In: N. Denzin and Y. Lincoln (Eds.), Handbook of Qualitative Research. London: SAGE.

Namsone D. (2010). Dabaszinātnes skolāa-atbilstoši laikam. Lielvārds.

Namsone, D. \& Cakane, L. (2014). How Teachers Can Learn to Reflect and Collaborate: Experiences from Latvia. In: C. Bolte, F. Rauch, (Eds.), Enhancing Inquiry-based Science Education and Teachers' Continuous Professional Development in Europe: Insights and Reflections on the PROFILES Project and other Projects funded by the European Commission (pp. 80-82). Berlin: Freie Universität Berlin (Germany) / Klagenfurt: Alpen-Adria-Universität Klagenfurt (Austria).

Niaz, M. (2011). Innovating Science Teacher Education. A History and philosophy of Science perspective. New York and London: Routledge.

Niemi, H., \& Jakky-Sihvonen, R. (2009). Teacher education curriculum of secondary school teachers. Revista de educacion, 173-202.

Olson, J. (2003). School technology education: the search for authenticity. In: E.W. Jenkins (Eds.), Innovations in science and technology education. Vol. VIII. Paris: UNESCO Publishing. 
Pavlova, M., Pitt, J. (2003). Technology education in the Russian Federation: is the perspective clear? In: E.W. Jenkins (Eds.), Innovations in science and technology education. Vol. VIII. Paris: UNESCO Publishing.

PROFILES Project. http://www.profiles-project.eu/work_packages/index.html

Rauch,F., Dulle,M., Namsone,D., Gorghiu,G. (2014). PROFILES Networks: Three International Examples. Science Education International. 25(2), 97-114.

Šapkova, A. (2013). Study on Latvian Mathematics Teachers' Espoused Beliefs about Teaching and Learning and Reported Practices. International Journal of Science and Mathematics Education,11(3), 733-759.

Study programme Teacher of Natural Sciences and Information Technology http://www.lu.lv/gribustudet/katalogs/katalogi-anglu-valoda/study-programmecatalog/?user_phpfileexecutor_pi1[program_id] $=21219$

Van Driel, J., Beijaard, D., \& Verloop, N. ( 2001). Professional development and reform in science education: the role of teachers' practical knowledge. Journal of Research in Science teaching, 38(2),137-158.

Volkinsteine, J., Namsone, D., Cakane, L. (2014). Latvian chemistry teachers' skills to organize student scientific inquiry. Problems of education in the 21st Century, 59, $86-$ 98 . 